\title{
Fairy Tale, Tragedy, Fantastic: Three Generic Exceptions in the Short Stories of Anita Desai
}

\section{Elsa Lorphelin}

\section{Q OpenEdition}

1 Journals

Electronic version

URL: http://journals.openedition.org/ces/4197

DOI: $10.4000 /$ ces.4197

ISSN: 2534-6695

Publisher

SEPC (Société d'études des pays du Commonwealth)

\section{Electronic reference}

Elsa Lorphelin, «Fairy Tale, Tragedy, Fantastic: Three Generic Exceptions in the Short Stories of Anita Desai », Commonwealth Essays and Studies [Online], 43.1 | 2020, Online since 30 October 2020, connection on 09 November 2020. URL : http://journals.openedition.org/ces/4197 ; DOI : https:// doi.org/10.4000/ces.4197

This text was automatically generated on 9 November 2020 .

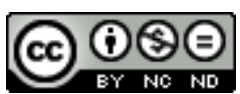

Commonwealth Essays and Studies is licensed under a Licence Creative Commons Attribution - Pas d'Utilisation Commerciale - Pas de Modification 4.0 International. 


\title{
Fairy Tale, Tragedy, Fantastic: Three Generic Exceptions in the Short Stories of Anita Desai
}

\author{
Elsa Lorphelin
}

1 As a writer, Anita Desai is mainly known for her novels. Clear Light of Day (1980), In Custody (1984), Baumgartner's Bombay (1988), among others, are set in India, yet constantly explore the cultural and social hybridity of a modern, postcolonial, sometimes Westernized India, in which characters find themselves trapped between tradition and modernity, and between marginality and society. The same goes for her short stories, published in Games at Twilight (1978), Diamond Dust and Other Stories (2000) and The Artist of Disappearance (2011). Despite their realism, Desai's novels and stories occasionally rub shoulders with other genres, such as the fairy tale or tragedy. Borrowing from the latter can be interpreted as a general aesthetic choice, since most of her work shares a sense of innocence and tragedy that results precisely from the inescapable state of entrapment experienced by naive or inexperienced characters, who are often female. In her first novel, Cry, the Peacock (1963), the young and innocent heroine's psyche slowly dissolves into madness after her marriage, prompting her to kill her husband and commit suicide. In Fire on the Mountain (1977) also, a young girl, Raka, sets fire to the mountains in a highly symbolic gesture, trying to escape her feeling of alienation and suppressed hatred for the world.

Progressively though, and especially in Desai's later novels, tragedy ceases to be a feminine prerogative, and distantiates itself from the fairytale-like quality of the heroines' inner worlds, to become a more universal burden, shared by all individuals. For instance, Baumgartner, the main character of Baumgartner's Bombay, after a life spent trying to escape his personal experience of the Holocaust, ironically dies in India at the hands of a German misfit he was trying to help. Deven, in In Custody, cannot seem to escape the announced catastrophe of his meeting with a great Urdu poet, for whose so-called human greatness the hero will be driven to social and material destitution. 
But if tragedy often colours Desai's novels and stories, it is made manifest in the title of one of her short stories, "Diamond Dust: A Tragedy". There, tragedy appears through its distinctive characteristics: hubris, hamartia, forebodings and omens, even though they are diluted in the modernist unimpressiveness of both settings and characters, which do not possess the social and personal grandeur of classic tragic heroes and places. Present yet subverted, tragedy in Desai's story deserts the city-state of Greek Antiquity and is reinvested in the banality of India's daily life. Thus, still retaining its universalizing and didactic dimension, it is concealed by the normality of its heroes and locations. Two other short stories, "The Rooftop Dwellers" and "The Man Who Saw Himself Drown," stand out for similar reasons: their realism is either mixed with elements from the fairy tale, or even undermined altogether by the addition of fantastic elements.

4 I would like to focus on these stories, to the extent that they constitute notable exceptions in the overall production of Anita Desai. Their deviation from strict realism entails a questioning about genre: why are those stories so keen on blurring generic boundaries, and what kind of interpretation does this suggest? For as we shall see, these particular stories - whether they tackle gender issues or display an interest in the question of Otherness - use and relocate these very Western genres in an Indian environment. Relying, in their elaboration, on generic and diegetic hybridity, I contend that these rewritings of Western genres serve a wider reflection on literary authority in a postcolonial context.

\section{The short story and the question of genre}

5 As far as the short story is concerned, the genre already carries an undecidedness that inherently seems to imply hybridity. As Liliane Louvel and Claudine Verley argue in their Introduction à l'étude de la nouvelle (1995), one of the characteristics of the genre is that "it escapes all attempts at a definition" (Louvel and Verley 1995, 18; my translation). ${ }^{1}$ therefore marking its generic versatility and elusiveness as an essential marker of the form. Its uniqueness, at the very least, seems to reside mainly in its brevity and in its treatment of time. This is all the more interesting when we consider Desai's thematic sympathy for tragedy, a genre that generally implies long periods of time and a nearly mythical slowness of events that grants tragedy its immutable character. A similar conception of time applies to fairy tales, which might happen to be brief but always convey a sense of out-of-timeness. On the other hand, the short story's "fragmentary" dimension would suggest a total incompatibility with the demanding genre of the tragedy, in which the most minute elements participate in the lengthy and intricate weaving of a fateful plot that will tighten its snare around the tragic hero's neck. The same goes, to some extent, for fairy tales. Although the supernatural is more inclined towards fragmentation, through the use of ellipses for instance, this genre generally rejects the anecdote (which is so dear to the genre of the short story) in favour of a conception of time that borders on eternity and grants it the same immutability as tragedy or myths. Even though Nicole Belmont, in her book Poétique du conte : essai sur le conte de tradition orale, recalls that nineteenth-century scholars, during the heydays of the genre of the tale, considered it as a "product of the degeneration of myths" (Belmont 1999, 34; my translation), ${ }^{2}$ we can yet point out apparent generic incompatibilities between the genres that are combined in Desai's stories: myths, 
tragedies and tales all work toward a sense of eternity, of permanence, while the short story focuses on instantaneity, as shown in Nadine Gordimer's expression "the flash of fireflies" (Gordimer 1968, 178-80), which illustrates the elusive and ephemeral quality of the moments that the short story aims at capturing.

\section{Tragedy in prose}

6 It is therefore all the more intriguing to find, in the collection of short stories entitled Diamond Dust, an eponymous story whose full title is "Diamond Dust: A Tragedy," for this adjoining of the word "tragedy" rejects the idea of the tragic as a mere "colouring" of the short story, and entails a generic questioning. The plot itself humouristically subverts the nobility of tragedies, by narrating the symbiotic and unreasonable relationship between the main character, Mr Das, and his dog Diamond, a mixed-breed mongrel whose unpredictable behaviour terrifies the neighbourhood, and whose incessant habit of running away will cause Mr Das to be hit by a car. More grotesque and farcical in appearance, the plot of the story immediately debunks tragic expectations. Mr Das's honourable position as a state official offers no protection against his embarrassing affection for the dog, causing the community to severely disapprove:

They had caught him, as portly and stiff as any of them, romping ridiculously in a rose garden enclosed by crumbling, half-ruined walls that he imagined hid him from view, chasing or letting himself be chased around the rose beds by a wildwith-excitement dog whose barks rent the peace of the morning park. They hardly knew how to tell him he was making a fool of himself. (Desai 2000, 52)

Not only does this description of Mr Das's fooling around with his dog insist on the notion of taboo ("they had caught him"), it also mixes farce with a simulacrum of sexual intercourse. The unflattering description of the character ("portly and stiff") is reinforced by the adverb "ridiculously" and by the verb "to romp" which recalls a filiation with the genre of the farce, of comedy. Mr Das is turned into a clownish figure ("he was making a fool of himself") and yet, this scene is depicted as a love - or physical - encounter. The "rose beds" suggest a conjugal bed and the "crumbling, half-ruined walls," a secret location where lovers might meet (Shakespeare's A Midsummer Night's Dream comes to mind here, and more particularly the wall scene from Pyramus and Thisbe, also fraught with bawdy references). In this light, the word "romping" becomes a euphemism for sexual intercourse, which is emphasized by the depiction of the "wildwith-excitement dog." The tragic fault therefore seems to build up right there, and to derive from an unnatural relation between the man and his dog that endangers order inside the community.

7 The latter, often referred to as an anonymous yet omnipresent "they," comments on Mr Das's capricious and, in this description, nearly romantic behaviour, and can be seen as a true Senate of the Antiquity, discussing and debating the attitude of a citizen whose embarrassing carelessness is a shame for the city:

It was - had been - a friendly, peaceful neighbourhood, after all, built for government officials of a certain cadre: all the men had their work in common, many were colleagues in the same ministries, and it would not do to have any enmity or public airing of personal quarrels. It was quite bad enough when their wives quarrelled or children or servants carried gossip from one household to another, but such things could not be allowed to get out of control. Propriety, 
decorum, standards of behaviour: these had to be maintained. If they failed, what would become of Bharti Nagar, of society? (Desai 2000, 59)

Propriety, decorum, standards; those words recall the strict rules of Ancient Greek society that work as a safeguard against any form of deviance that might endanger the stability and order of the community. As such, Mr Das, who seems to be reverting to a natural state in the presence of his dog, threatens the harmony and pastoral quality of the city and therefore becomes expendable in the eyes of his peers. As in a classic tragedy, Mr Das's fate seems to be sealed by his own marginality, his disregard for propriety, his improper love for an untamed beast, which justifies in itself his being cast out of society.

The voice of the community, which reminds one of the chorus in Attic drama, is further emphasized by the character of Mr Das's wife, whose isolated yet recurrent interventions and constant disapproval of her husband turn her into a Greek coryphaeus. Her warnings concentrate the sense of doom and inevitability that pervades the short story, as if she were channeling the tragic strength of the genre:

He felt he was coming down with the flu, but he would not give up, he would not leave Diamond to the dire fate Mrs Das had prophesied for him. A kind of mist enveloped the city streets - whether it was due to the dust, the exhaust of tired, snarled traffic or the cold, one could not tell, but the trees and hedges loomed like phantoms, the streetlamps were hazy, he imagined he saw Diamond when there was no dog there, and he was filled with a foreboding he would not confess to Mrs Das who waited for him at home with cough mixture, hot water and another muffler. "Give him up," she counselled grimly. "Give him up before this search kills you." (Desai 2000, 62)

In this short passage, Mrs Das appears both as a dutiful wife and as a dreadful oracle sharing her visions with the tragic hero. The solemnity of the premonition, conveyed by the repetition of "give him up" and the abrupt conclusion "before this search kills you," along with the disquieting presence of "phantoms," of "haze," of "mist," and of the hallucinatory visions of the man, further reinforce the feeling of a tragic destiny awaiting Mr Das. When tragedy strikes, before the main character is hit by the pound van, it is subverted by the prosaic depiction of the catastrophe, that again borders on the grotesque, for the witnesses are said to see "the small man in his tight brown coat, his woollen cap and muffler, dash down his market bag into the dust, and chase the van with a speed no one would have thought possible" (Desai 2000, 63). Far from the stature and exceptionalism of the classic tragic hero, Mr Das's tragedy is all the more poignant as it is highly plausible and therefore relatable.

9 In this rewriting of a tragedy, first, dialogue is replaced by narration, thus removing one major element of tragedy: its theatricality. Yet, the latter is to be found in the theatricality of the characters' personalities, a transformation that nevertheless subsequently shifts the tone of the plot from pure tragedy to comedy, as seen in the many ironic descriptions that are made of Mr Das and his wife. Somehow turned into the traditional duo of the unfaithful husband and the shrew, the characters of this socalled tragedy challenge the typology of the traditional genre.

Thematically, both tragedy and the short story seem to hold qualities that make sense of this mixing of the two genres. First of all, the question of marginality is central in both: whether it is the marginality of the tragic hero whose destiny sets him aside from the rest of humanity, or that of the short story characters, the "submerged population" as Irish writer Frank O'Connor called them to refer to the necessary exile undergone by those characters. He added, "Always in the short story there is this sense 
of outlawed figures wandering about the fringes of society, superimposed sometimes on symbolic figures whom they caricature and echo - Christ, Socrates, Moses" (1962, 19). Therefore, myths, tragedies and short stories encompass a number of characteristics that seem to bring them closer than initially imagined, at least in terms of the characters they portray.

11 Another one of those characteristics is the notion of "catastrophe." The etymology of the word, which means "turning point," or "overturning," recalls one of the specificities of the genre of the short story, about which Daniel Grojnowski explains that it "relates in a limited number of pages something that happens" (quoted in Louvel and Verley 1995, 17), a particularity confirmed by Marie-Louise Pratt's assertion: "The short story deals with a single thing " $(1981,184)$. In "Diamond Dust," the depiction of the catastrophe in the tragic sense of the term appears as very similar to the short story's modernist epiphany, if only through the lexical field of illumination that is used by Desai: "But when tragedy struck, it did so in broad daylight, in the bright sunshine of a winter Sunday" $(2000,63)$. The last sentences of the story, which depict the pound van carrying the dog away, borrows from the same imagery, albeit slightly differently: "Behind the bars of the window receding into the distance, Diamond glittered like a dead coal, or a black star, in daylight's blaze" (63). The predominance of light that announced the dénouement/revelation of the story is again present yet invalidated by oxymoronic associations such as the "glittering of dead coal" or that of "a black star," thereby reuniting at the same time the illuminating quality of the tragedy's catastrophe, and the opaque epiphany of modernist short fiction.

But mostly, what this convergence does to tragedy is that it trivializes it and undermines its authority as a noble and codified genre. Set in India, the Western tragedy is here exoticized, while at the same time legitimizing mundane incidents as worthy of being labelled "tragedies." Tragedy is therefore no longer the privilege of European royals, nobles or aristocrats, but a genre that applies to third-world reality as well.

\section{Fairy tale}

Tragedy is not the only genre that Desai associates with her stories in the collection Diamond Dust. For in this particular collection, two other short stories stand out. Not carrying any subtitle this time, as if to mingle, unnoticed, among the more traditional realistic short stories of the collection, they nevertheless question the plasticity and "polysyntheticism" of short fiction (Louvel and Verley 1995, 25) by borrowing from other traditions. It is the case of the story entitled "The Rooftop Dwellers," which narrates the life of Moyna, a young Indian woman who starts working and settles down in her own place, a "barsati," that is to say, in this case, a cheap makeshift apartment built on the roof of her owners' house. While working at her own independence she discovers the existence of a whole community of people living on the roofs of Delhi and whose lives on the rooftops seem to obey a parallel code of conduct, completely disconnected from that of the people living below. Artificially recreating a caste of destitute citizens, these barsatis shelter marginals, social outcasts, and contribute to form an unacknowledged and at times rejected bond between them, which is mainly the result of these people's subjection to the inquisitive rules of house owners and to the voyeuristic urge of male rooftop tenants. Despite the sordidness of this reality, 
"The Rooftop Dwellers" summons many aspects of the fairy tale, starting with its lexical field: "a weeping heroin," "trapped in a cell," "atrocities committed by a matron," a "pumpkin," an "empress with crowning glory," a "palace," adoptive parents, thieves, murderers, Russian folk tales, a "dragon lady," a mother-in-law, a "young gallant," "books on medieval trade," but also an insistence on growing up, an omnipresence of dreams, and the final liberation of the heroine. The main character, who first appeared as no more than a young woman on a quest for empowerment, actually turns out to be similar to a fairytale heroine, locked up in a tower whose entrance is guarded by a dragon (her owner), and longing for freedom.

Generic hybridity is further developed by the juxtaposition of this modern fairy tale with references to the mythological sagas and epic narratives of Indian folklore. Indeed, the family who rents the barsati to Moyna spends most of its time watching TV:

You have come just at Mahabharata time, the woman crosslegged on the bed reproached her. [...] The two children stared at her for a bit, impassively, then went back to picking their noses and following the episode of the Mahabharata that the whole city of Delhi watched, along with the rest of the country, on Sunday evenings - everyone, except for her. (Desai 2000, 159)

And further:

Although she did not bring it up directly, after that whenever Moyna encountered them, on her way to work or back, they never failed to refer obliquely to that evening. "You are having more guests tonight?" they would ask when they saw her returning with the shopping she had done along the way. "No? Then why not come and watch TV tonight? Ramayana is showing at seven p.m. Very fine film, Ramayana. You should join us," they commanded, as if testing her true colours. (183)

The reference to these sagas, which modernity has turned into mass entertainment and whose traditional storyteller is now a TV set, marks their uprooting from their initial context, that of orality and cultural transmission of a shared heritage. Ironically, the tales that once brought the Indian community together, narrated as they now are by an appliance, isolate even the members of the family nucleus in this simulacrum of family time. Worse, the communitarianism that derives from watching them ("that the whole city of Delhi watched, along with the rest of the country - everyone except for her") borders on segregation, as Moyna, who does not watch TV, becomes the outsider, the troubling figure of the "Other."

Therefore, the elements borrowed from the tale, even as they thrive in the short story, are either empty signifiers for objects that are nowhere to be found in Moyna's life (the prince, for instance, is nowhere to be found), or a liminal space where the so-called fairy tale becomes subverted into an acerbic depiction of what life holds for ambitious young women in India, when they decide not to abide by the rules of family and society. For after all, the short story ends on a letter from Moyna's mother begging her daughter to accept an arranged marriage, and on the memory of a female acquaintance's acceptance into a convent. The relief felt by the girl's father echoes the request of Moyna's parents. In this story as in India as a whole, not much seems to be expected from girls except that they should be provided for.

It is worth noting that, of all genres, the fairy tale should be the one that is subverted in a text dealing with female emancipation, inasmuch as it has been known for its traditionally stereotypical depiction of female characters, along with a compliance with a patriarchal system of values. Genre and gender are intertwined, and, even though the tale here loses its didactic and pedagogical aspects, its inclusion into a specific time and 
geographical location makes it more relevant to a particular era and culture. If the tale is more inclined to deal with political considerations, it might be because "it is not tales that stage political stakes as much as political powers that take on the appearance of fairytales" (Méchoulan 2006, §1; my translation). ${ }^{3}$ Thus, the arbitrariness of some social codifications (men/women relationships, male domination or taboos, for instance) are generically transposable into the absurdity of the tale. Auxiliaries and opponents cease to be archaic stereotypes to become realistic individuals that contemporary characters come across daily. As Eric Méchoulan explains, "regularly, tales stage kings, princesses, inherited powers, conquered provinces or deserved sovereignties. Power games crowd fabulous tales" (Méchoulan 2006, \$1). ${ }^{4}$ It is therefore not surprising that in a postcolonial context and under the pen of female writers, the genre of the tale should be so popular. Emptied out of a purely magic dimension that is sometimes replaced by magic realism, the tale sheds light on matters of power, domination, and on the rejection of those.

\section{Fantastic}

The last short story that I would like to discuss, entitled "The Man Who Saw Himself Drown," is to some extent even more confusing than the other two. Its affiliation to the fantastic genre, which distinguishes it from the usual preferences of Anita Desai, makes it significantly disconcerting. In his Introduction to Fantastic Literature, Tzvetan Todorov reminds us that:

In a world that is indeed ours, the world that we know, empty of devils, sylphs and vampires, an event takes place that cannot be explained by the laws of that very familiar world. The witness of the event has to choose between two possible solutions: either it is an illusion of the senses, a product of imagination and natural laws apply; or the event actually took place, it is part of reality, but then this reality is ruled by laws unknown to us. [...] The fantastic is the hesitation felt by a being who knows nothing but natural laws, faced with an event that is, in appearance, supernatural. (Todorov 1976, 29; my translation) ${ }^{5}$

This is indeed what "The Man Who Saw Himself Drown" depicts, since it tells the story of a man who, literally, witnesses his own drowning and finds himself compelled to disappear from his own life. As such, it falls into the fantastic category, even though the mysterious death of the character is the only element that links the story to the genre:

Every detail, in every detail, he was myself: I was looking at myself - after having spent half an hour, or an hour, underwater, sodden with river and mud - but it was I, in every detail, I. It was as though I was lying full-length, suspended in mid-air, and gazing down at my own reflection below, soaked and muddy, but myself, I, after an accident in the river. (Desai 2000,88)

We nevertheless quickly notice that even though death is the main disruptive element in the text, the one that defies Todorov's laws of nature and transforms our world into one where a man may concurrently die and survive death, it is not death itself but the splitting into two that results from it that plunges the character - and the reader - into horror. From analyzing this quote, we can notice an almost frenetic and chaotic multiplication of the pronouns. In four lines, "myself" is repeated four times while "I" is repeated five times; and the third-person "he" only appears once, as if grammatically marking the impossible identification, or coincidence, between the narrator and the corpse. The repetitions emphasize the incredulity of the character and his obsession 
with details ("every detail" appears three times) illustrates his inability to make sense of this extraordinary situation. The play with the pronouns insists on, and semantically materializes, the generic split at play inside the diegesis. In this extract, the assertion according to which "he was myself" is so hard to comprehend that it forces the narrator to try and justify it. The colon shows a desire to explain, and in a first attempt, the rephrasing into "I was looking at myself" re-categorizes the text into the realm of the bizarre, more rationally acceptable than the fantastic. If it happened to be a mere resemblance between the narrator and the corpse, then the laws of nature would still apply and the situation could be explained. But the interpolated clause, that desperately aims at establishing a reassuring alterity between the narrator and the dead man by listing the latter's singularities, is quickly invalidated by the conclusion "it was I." Here, the pronoun "it" concentrates the horror of the identification process, not only between the self and an "Other" that is so similar, but - as also implied by the use of the past tense - between the self and a dead "Other." The passage constantly hesitates between distantiation (as exemplified by the theme of reflection - "gazing down at my own reflection" - that circumvents and delays the fusion between the "I" and the "it"), and a denied identification. The latter nevertheless manages to force itself onto the text, by progressively removing the "he" and "it" pronouns, replacing them with a final "myself, I," that binds the two entities, the narrator and the drowned body, in a tacit recognition that this "Other" is also and irremediably an "I."

The initial amusement felt by the character at what, to him, is most certainly a misidentification, soon gives way not only to the horror of beholding his own dead self, but to the impossibility of making sense of an existence that has legally, and officially, declared him dead. Denied a civil existence whereas he is alive, he is condemned to a life of aimless wandering. The whole narrative also carries a mark of this identity break, if only through the abrupt shift - in the middle of the story - from a thirdperson narration to a first-person one, as if external focalization, or the possibility of being "seen," "accounted for" by a third party, suddenly became impossible in the very core of the story. Being denied an existence in the eyes of the Other (even if this "Other" is the narrative persona), the main character's life becomes pointless and tragically non-desirable. From that point on, the character's only obsession becomes "to drown this self that had remained, to drown the double of the self that had already died" (Desai 2000, 98). The confusion between the notions of "self," "other" and "double" brings about a feeling of defamiliarization and fragmentation that culminates in the oddity of the mere presence of such a story in the production of Anita Desai. While pondering on the meaning of his "non-existence," the protagonist observes:

I began to see that all of life was divided in two or into an infinite number of fragments, that nothing was whole, not even the strongest or purest feeling. As for the way before me, it multiplied before my eyes, the simplest question leading to a hundred possible answers. (92)

This could be, in a way, a valid definition of the genre of the short story, exposing its open-endedness together with its hermetic nature and resistance to easy interpretation. The story performs one last trick on us, when nearing its ending. Another sudden break in the diegesis and return to a third-person narrative gives us to see, in a very distantiated way, with a visual effect that borders on the cinematographic, the drowned and dead body of the protagonist, who one line before was rejecting the idea of killing himself:

At daybreak the child with the pot returned to the river for water. What he saw made him stop and stare, first from the slope of the bank, then from closer up, the 
stones in the shallows. When he made out it was a man's body that lay in that trickle, face down, he dropped the pot on the stones in fright. Its clattering rang out so loud and clear, a flock of crows settling on the sands in curiosity took off in noisy flight. (99)

Taking the reader completely by surprise, the short story once again debunks our expectations, by making up for its brevity and multi-layered opacity through the unlimited and "fantastic" possibilities it opens up in terms of interpretation. In the context of postcolonial literature, one might indeed wonder about the aesthetic and political significance of defamiliarizing traditional genres such as the tragedy, the fairy tale or the fantastic story. Their inclusion in short stories, which already point toward hybridity and undecidedness, further complexifies the question. An answer can be found in the use of magic realism by postcolonial writers, since "the magic realist texts tend to display a preoccupation with images of both borders and centers and to work toward destabilizing their fixity" (Slemon 1995, 412). It is not images but genres whose fixity is here destabilized, as they find themselves rewritten and modernized. They nevertheless all retain a magical dimension. In the case of "Diamond Dust," it lies in the mythical presence of fatum, of a mysterious masterplan that directs the fate of Mr Das. In "The Rooftop Dwellers," as we said, intertextuality constantly relocates Moyna's story in the realm of a subverted fairy tale. As for "The Man Who Saw Himself Drown," the narrative keeps on hesitating between realism and the supernatural. Further elaborating on magic realism, Stephen Slemon contends that:

The term 'magic realism' is an oxymoron, one that suggests a binary opposition between the representational code of realism and that, roughly, of fantasy. In the language of narration in a magic realist text, a battle between two oppositional systems takes place, each working toward the creation of a different kind of fictional world from the other. Since the ground rules of these two worlds are incompatible, neither one can fully come into being, and each remains suspended, locked in a continuous dialectic with the 'other,' a situation which creates disjunction within each of the separate discursive systems, rending them with gaps, absences, and silences. $(1995,409)$

21 We might thus argue that the generic instability that is to be noticed in the three selected short stories stages issues that are eminently postcolonial. They articulate Western genres with a strictly Indian rewriting of those, and thereby unsettle traditional expectations and open up new interpretative horizons. For the dialectic mentioned by Slemon, the "separate discursive systems," is precisely what structures these stories: Mr Das's awful death is constantly challenged by comedic elements that make it grotesque rather than tragic, Moyna's life is anything but a fairy tale, and death in "The Man Who Saw Himself Drown" is what dissociates reality and fantastic, thus triggering the character's epiphany about the relativity of perception that is so reminiscent of magic realism ("I began to see that all of life was divided in two or into an infinite number of fragments, that nothing was whole," 93).

These three stories therefore, though they may strike the reader as exceptions in Anita Desai's overall production, rather epitomize what many of her other stories address, thematically speaking. They displace and relocate postcolonial questionings inside their own structures - by degrading and trivializing the tragedy, subverting the fairytale or making Otherness a central and unifying concept. They offer an example of "writing back" that does not aim at undermining imperial or metropolitan discourses so much as deconstructing the literary forms that constitute them, thus also reclaiming these genres as postcolonial ones, able to encompass Indian reality. 


\section{BIBLIOGRAPHY}

BELMONT, Nicole. 1999. Poétique du conte : essai sur le conte de tradition orale. Paris: Gallimard.

DESAI, Anita. 2000. Diamond Dust and Other Stories. London: Chatto \& Windus.

GORDIMER, Nadine. 1968. "The Flash of Fireflies.” Kenyon Review 30: 178-80.

LOUVEL, Liliane, and Claudine VERLEY. 1995. Introduction à l'étude de la nouvelle. Toulouse: Presses

Universitaires du Mirail.

MECHOULAN, Eric. 2006. “Le Pouvoir féérique.” Fééries 3. Posted online 5 February 2007. http://

journals.openedition.org/feeries/138.

O'CONNOR, Frank. 1962. The Lonely Voice. London: Macmillan.

PRATT, Marie-Louise. 1981. “The Short Story: The Long and the Short of It.” Poetics 10: 175-94.

SLEMON, Stephen. 1995. “Magic Realism as Postcolonial Discourse." In Magical Realism: Theory,

History, Community, edited by Lois Parkinson Zamora and Wendy B. Faris, 407-26. Durham: Duke

University Press.

TODOROV, Tzvetan. 1976. Introduction à la littérature fantastique. Paris: Seuil.

\section{NOTES}

1. "Un genre dont la caractéristique principale semble bien être qu'il échappe à toute tentative de définition."

2. "La position nuancée des frères Grimm concernant les rapports du mythe et du conte sera durcie par les savants du XIX ${ }^{e}$ siècle, qui ne verront dans le second qu'un produit de la dégénérescence du premier."

3. "[C]e ne sont pas tant les contes qui représentent des enjeux politiques, ce sont les pouvoirs en place qui prennent l'allure de contes de fées."

4. "Les contes, régulièrement, mettent en scène rois, princesses, pouvoir hérités, provinces conquises ou souverainetés méritées. Les jeux du pouvoir occupent beaucoup les récits fabuleux." 5. "Dans un monde qui est bien le nôtre, celui que nous connaissons, sans diables, sylphides, ni vampires, se produit un événement qui ne peut s'expliquer par les lois de ce même monde familier. Celui qui perçoit l'événement doit opter pour l'une des deux solutions possibles : ou bien il s'agit d'une illusion des sens, d'un produit de l'imagination et les lois du monde restent alors ce qu'elles sont ; ou bien l'événement a véritablement eu lieu, il est partie intégrante de la réalité, mais alors cette réalité est régie par des lois inconnues de nous. [...] Le fantastique, c'est l'hésitation éprouvée par un être qui ne connaît que les lois naturelles, face à un événement en apparence surnaturel." 


\section{ABSTRACTS}

Focusing on Anita Desai's collection Diamond Dust and Other Stories (2000), this article examines three short stories: "Diamond Dust - A Tragedy," "The Man Who Saw Himself Drown" and "The Rooftop Dwellers." Respectively borrowing from tragedy, the fantastic and the fairy tale, they use the generic malleability of the short story and entail a questioning of the hybrid nature of this literary genre. The notion of hybridity also resonates as a political strategy of ideological and formal subversion, and this article examines the possible link between the hybrid generic nature of those three texts, and the themes they explore - gender, otherness and Indian identity.

\section{INDEX}

Keywords: Anita Desai, short stories, postcolonial, hybridity, genre, otherness, gender

\section{AUTHOR}

\section{ELSA LORPHELIN}

Lycée militaire de Saint-Cyr / VALE, Sorbonne Université

Elsa Lorphelin is a teacher in preparatory class at the Military School of St Cyr l'Ecole. She is completing a PhD at the Sorbonne (Paris), entitled "Intertextuality, Interdiscursivity and Authority in the Short Stories of Jean Rhys, Janet Frame and Anita Desai." Her research interests include postcolonial literature, gender studies, authority, intertextuality and discourse analysis. She has published "Ending(s), Seriality and Interdiscursivity: The Paradox of the Collection of Short Stories in the Works of Jean Rhys and Janet Frame" in Sillages Critiques $(24,2018)$ and "The Voices of Others: Intertextuality and Authorial Presences in Jean Rhys's Short Fiction" in Women: A Cultural Review $(31,2020)$. 